
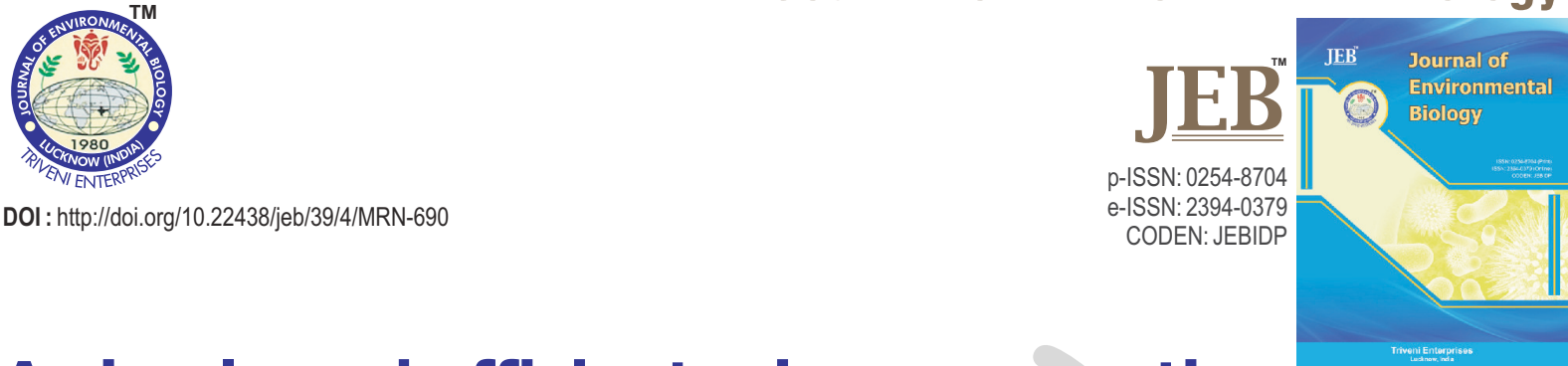

\title{
A simple and efficient micropropagation protocol for New Guinea Impatiens (Impatiens hawkeri)
}

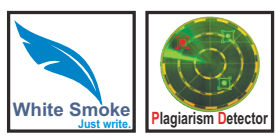

Authors Info

L. Samiei ${ }^{1 *}$, M. Davoudi Panhehkolayi ${ }^{2}$, H. Mirshahi', and Z. Karimian'

1 Department of Ornamental Plants, Research Center for Plant Sciences, Ferdowsi University of Mashhad, Mashhad, 91775-1653, Iran

${ }^{2}$ Department of Horticulture, College of Agriculture, Ferdowsi University of Mashhad, Mashhad, 91775-1653, Iran

*Corresponding Author Email : samiei@um.ac.ir

Key words Apical bud Benzyl amino purine Impatiens hawkeri Nodal explant Kinetin

Publication Info Paper received : 10.07.2017 Revised received: 03.11.2017 Re-revised received: 02.12.2017 Accepted : 22.12.2017

\section{Abstract}

Aim : The study aimed to compare the potentials for in vitro regeneration of apical and nodal explants of New Guinea Impatiens in the presence of cytokinins and to develop a simple, fast, cost-effective and efficient protocol for micropropagation of this valuable plant species.

Methodology : Due to high rate of contamination of Impatiens explants in in vitro conditions, a preliminary experiment was performed on surface sterilization of the bud explants using various sterilization reagents. In addition, the effects of various concentrations of benzyl amino purine and kinetin on proliferation of apical and axillary bud explants were investigated. Following two subcultures in multiplication media, the plantlets with well-developed roots were directly transferred to plastic cups and later to the greenhouse for acclimatization.

Results : The most effective sterilization procedure, which resulted in $75 \%$ healthy explants, was recognized when the bud explants were disinfected with $0.1 \%$ mercuric chloride -6 min - followed by a culture on Murashig and Skoog medium, consisting of $300 \mathrm{mgl}^{-1}$ Cefotaxime. Also, the results revealed that axillary buds were more efficient in inducing higher adventitious shoot regeneration compared to apical buds, when they were exposed to $0.5 \mathrm{mg} \mathrm{I}^{-1}$ BAP in MS medium. In addition, the in vitro roots were simultaneously induced during shoot proliferation and maximum generated root number was observed in the medium containing $1 \mathrm{mg} \mathrm{I}^{-1} \mathrm{BAP}$ ). The results showed that about $95 \%$ of the regenerated plantlets survived, acclimatized successfully and continued their normal and vigorous growth in the greenhouse.

Interpretation: The findings of this study indicated that the use of axillary buds in the presence of low concentrations of BAP were effective in multiplication of New Guinea Impatiens. The simultaneous occurrence of rooting during proliferation was beneficial in significantly reducing the time and cost of micropropagation procedure. The results propose a simple, fast, efficient and economic protocol that can be easily commercialized for micropropagation of Impatiens hawkeri'Cherry Red'.

\section{Micropropagation of New Guiea Impatiens}

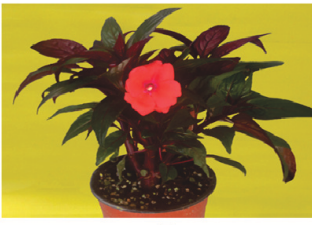

$\sqrt{2}$
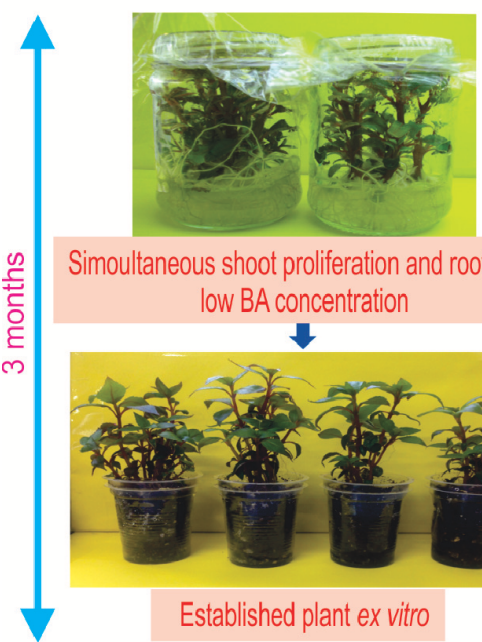

Simoultaneous shoot proliferation and rooting in low BA concentration

$\checkmark$

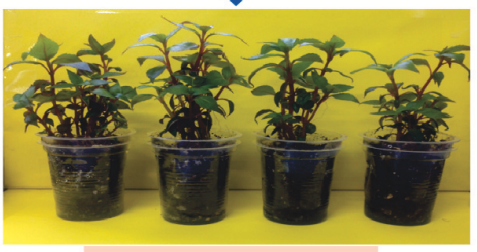

Established plant ex vitro 


\section{Introduction}

New Guinea Impatiens (Impatiens hawkeri W. Bull) is one of the most valuable pot and bedding plant, rich in flower color, with a relatively long-lasting flowering period. The ever-increasing demand for this plant during recent years indicates its growing popularity (Ronghua and Zheng, 2006; Kim et al., 2014). New Guinea Impatiens is conventionally propagated through cutting, (Dostal et al., 1991; Ronghua and Zheng, 2006; Stephens 1998), however, this method always encounters various limitations, including availability of sufficient plant stock materials, as well as disease outbreak among propagules due to primary infection of mother plants (Ramsehh et al., 2009; Shukla and Khare, 2012). In recent years, demand for healthy and quality plant materials have increased extensively for commercial production of ornamental plants. Plant tissue culture is widely used as an alternative approach to conventional propagation methods in floriculture industry, as it allows access to more consistent and quality products (Jain and Ochatt, 2010).

A number of studies have been performed to verify the success of in vitro techniques for micropropagation of related species of Impatiens like Impatiens balsamina (Taha et al., 2009), l. repense (Herath and Wijesundara, 2010), I. waleriana (Witomska and Lukaszewska, 2003), I. flanganae (Nikolova et al., 1996), however, studies on the micropropagation of Impatiens hybrids is limited. There are several parameters that have already been identified as contributing factors in the success of the plant micropropagation procedure, including the size and source of the explant, plant growth regulators, and the type of culture media. These factors have been manipulated in various studies to establish an optimum in vitro culture protocol (George, 1993; Kitto, 2015). While there are studies which indicate the advantages of using axillary bud explants in micropropagation (Kehie et al., 2012; Vasudevan and Van Staden, 2011), there are also others suggesting a high proliferation rate using apical bud explants (Kitto 2015; Salehi et al., 2014). In fact, Hans and Stephens (1987) reported shoot tip explant to be favorable in tissue culture of an intraspecific hybrid of Impatiens, whereas for in vitro culture of Impatiens repense, axillary bud indicated a better response (Herath and Wijesundara, 2010).

Tissue culture is accepted as one of the most popular and effective techniques in plant propagation, however, in vitro microbial contaminations are known as the main concerns for achieving a successful plant micropropagation procedure. Hence, establishing an efficient disinfection method to obtain sterile explants is a critical step in tissue culture studies (Niedz and Bausher, 2002; Tiwari et al., 2016). Previous studies have reported the presence of various pathogens, especially endogenous microorganisms in numerous indoor plants (Brunner et al., 1995; Fang and Hsu, 2012). In this study even a high rate of in vitro infections during micropropagation of Impatiens hawkeri were encountered. As a result, utilizing specific strategies for the eradication of viable microorganisms and establishing an aseptic culture for in vitro propagation of this plant was inevitable.
In view of the above, in this study the in vitro regeneration potential of apical and nodal explants of Impatiens hawkeri 'Cherry Red' was compared in the presence of cytokinins and an attempt was made to develop simple, fast, cost-effective and efficient protocol for micropropagation of this valuable plant species. In addition, as an essential step for the success of our protocol, an optimal sterilization procedure is presented in the study for efficient surface disinfection of bud explants of New Guinea Impatiens.

\section{Materials and Methods}

Disinfection assay : The Impatiens hawkeri 'Cherry Red' (20-25 $\mathrm{cm}$ in height) pots were purchased directly from the production area of this plant. The main shoots of each pot were cut on the base, the leaves were excised and the shoots were dissected to about 4-cm length segments each containing 2-3 buds. The segments were then disinfected by different sterilization procedures using ethanol, sodium hypochlorite, mercuric chloride or Cefotaxime. All the sterilization procedures are presented in Table 1. Following sterilization, the explants were rinsed three times with sterilized distilled water for $15 \mathrm{~min}$. Axillary buds with one $\mathrm{cm}$ length were excised and the explants were incubated in Murashige and Skoog medium (1962) containing $30 \mathrm{gl}$ ${ }^{1}$ sucrose devoid of plant growth regulators. Fourteen explants were used for each treatment and the experiment was repeated three times. The $\mathrm{pH}$ of the medium was adjusted to 5.8 using $\mathrm{HCl}$ and $\mathrm{KOH}$ before adding $0.8 \mathrm{gl}^{-1}$ agar and autoclaving at $121^{\circ} \mathrm{C}$ and $1.3 \mathrm{~K}$ $\mathrm{Pa}$ pressure for 20 minutes. The cultures were maintained at $25^{\circ} \mathrm{C}$ under $16 / 8 \mathrm{hr}$ light/dark regime with an average of $45 \mu \mathrm{molm}^{-2} \mathrm{~S}^{-1}$ irradiances provided by a white inflorescent tube. The percentage of fungal and bacterial contaminations were calculated by visual evaluation of the cultures for one month.

Effect of cytokinins on proliferation of apical and axillary bud explants : Shoot tip and axillary bud explants of approximate one centimeter were excised from sterilized in vitro shoots of previous experiments. The explants were

Table 1 : Sterilization treatments for disinfection of nodal explants of Impatiens hawkeri'Cherry Red'

\begin{tabular}{|c|c|c|c|c|}
\hline $\begin{array}{l}\text { Treatment } \\
\text { code }\end{array}$ & Ethanol & $\begin{array}{l}\text { Sodium } \\
\text { hypochlorite }\end{array}$ & $\begin{array}{l}\text { Mercuric } \\
\text { chloride }\end{array}$ & $\begin{array}{l}\text { Cefotaxime } \\
\text { in culture } \\
\text { medium }\end{array}$ \\
\hline 1 & $\begin{array}{l}70 \% \\
(30 \mathrm{~s})\end{array}$ & $1.5 \%$ (10 min) & - & - \\
\hline 2 & $\begin{array}{l}70 \% \\
\text { (30s) }\end{array}$ & $2 \%(10 \mathrm{~min})$ & - & - \\
\hline 3 & $\begin{array}{l}70 \% \\
\text { (30s) }\end{array}$ & - & $0.1 \%$ (6 min) & - \\
\hline 4 & $\begin{array}{l}70 \% \\
\text { (30s) }\end{array}$ & $1.5 \%(10 \mathrm{~min})$ & $0.1 \%$ (6 min) & - \\
\hline 5 & $\begin{array}{l}70 \% \\
\text { (30s) }\end{array}$ & $1.5 \%(10 \mathrm{~min})$ & $0.1 \%$ (6 min) & $300 \mathrm{mg} \mathrm{l}^{-1}$ \\
\hline
\end{tabular}


incubated in MS medium consisting of various concentrations of benzyl amino purine and kinetin, coupled with $300 \mathrm{mg} \mathrm{l}^{-1}$ Cefotaxime, $30 \mathrm{gl}^{-1}$ sucrose and $0.8 \mathrm{gl}^{-1}$ agar (Table 2).

The cultures were maintained under similar condition for sterilization. Two subcultures were performed at five-week interval and data for shoot number and length, leaf number and root number and length were recorded at the end of the second subculture. Three replications with ten explants per replicate were used for each treatment. Due to production of high quality roots during proliferation, the shoots were not transfered to the rooting media supplemented with auxin. Therefore, the plantlets with well-developed roots were directly transferred from proliferation medium to plastic cups containing sterilized peat:perlite (1:1) substrates and covered with plastic for acclimatization. After one month, the plantlet survival rates were recorded and the acclimatized plants were transferred to the greenhouse.

Data analysis : One-way analysis of variance was performed for both experiments using SPSS version 16.0 for the analysis of mean values of various treatments. The difference between the treatments were determined using Tukey test $(0.05)$.

\section{Results and Discussion}

The results of the study showed that surface disinfection with $70 \%$ alcohol (for 30 seconds) plus $0.1 \%$ mercuric chloride (for $6 \mathrm{~min}$ ), followed by the addition of $300 \mathrm{mg} \mathrm{l}^{-1}$ Cefotaxime in culture medium was the most effective method for sterilization of bud explants of New Guinea Impatiens (Table 2). Using this method, $75 \%$ of the explants survived and remained uncontaminated, while $97.5-100 \%$ of the explants were infected using other sterilization treatments. It should be noted that ethanol, sodium hypochlorite and mercuric chloride are the commonly used reagents for surface disinfection of plant tissues in tissue culture (Barampuram et al., 2014). Nevertheless the results clearly demonstrated that these compounds, when used alone, did not eradicate the microorganisms which might be due to the presence of endophytic microorganisms. These pathogens, whose growth were inhibited by Cefotaxime, exist in the internal tissues of the plants and cannot be easily removed by the common disinfectant agents. Therefore, they might be responsible for the observed extensive contamination of the impatiens explants in the current experiment. In fact, controlling endogenous bacteria or fungal infections has been a major issue in plant micropropagation studies (Brunner et al., 1995). Several studies have reported the challenges of eradicating endophytic microorganisms during micropropagation of several indoor plants. Some have shown incorporation of antibiotic compounds in the culture medium as an effective method for controlling the endophytic contaminations. Fang and Hsu (2012) reported severe bacterial contamination during tissue culture of various cultivars of Aglaonema, which was eventually controlled by adding various combinations of antibiotics in the culture medium.

The first symptoms of bud outgrowth were observed in axillary buds 7-10 days after culture initiation, however, apical buds began their growth 3-4 days later than that of axillary buds. This difference in the growth initiation can be attributed to the physiological differences of two explants, which arise from their position on the stem. Similar behavior has also been observed in the tissue culture of Mentha piperata, which caused the axillary buds to grow faster than apical buds (Ghanti et al., 2004). Table 3 summarizes the data on proliferation and shoot regeneration of Impatiens hawkeri explants when different concentrations of cytokinins were applied. In fact, the medium consisting of $0.5 \mathrm{mg} \mathrm{l}$ ${ }^{1}$ benzyl amino purine resulted in the maximum number of shoots (3.42 per explant) in axillary buds, while other media supplemented with kinetin resulted in least shoot initiation in the apical buds. In addition, nodal explants led to a higher shoot multiplication compared to apical explants at each cytokinin treatment, however, the differences were not significant. This can be attributed to the synthesis of auxin in shoot tips of apical explants, which induce apical dominance (Vasudevan and Van Staden, 2011). Furthermore, the increase in cytokinin oxidase activity in shoot tip explants can also reduce the amount of shoot proliferation in apical bud explants (Wang et al., 2009). Indeed, the results of the present experiment are consistent with the findings of other studies outlining higher proliferation rate of axillary buds compared to apical buds (Anjusha and Gangaprasad, 2016; Kehie et al., 2012). Regarding shoot proliferation, the shoot number was higher in the presence of benzyl amino purine compared to kinetin in the culture medium (Table 3). In fact, compared to the control, shoot multiplication was lower in kinetin supplemented media using both types of explants. These findings suggest that benzyl amino purine is more effective in inducing shoot multiplication of Impatiens hawkeri, which is consistent with the results of previous studies,

Table 2 : Percentage of in vitro fungal and bacterial contaminations of Impatiens hawkeri 'Cherry Red' explants treated with various sterilization procedures after one month of culture

\begin{tabular}{lllll}
\hline Treatment & $\begin{array}{l}\text { Fungi } \\
\text { contamination (\%) }\end{array}$ & $\begin{array}{l}\text { Bacterial } \\
\text { contamination (\%) }\end{array}$ & $\begin{array}{l}\text { Contamination } \\
\text { free (\%) }\end{array}$ & $\begin{array}{l}\text { Total } \\
\text { infection (\%) }\end{array}$ \\
\hline 1 & $30^{\mathrm{b}}$ & $70^{\mathrm{c}}$ & $0^{\mathrm{b}}$ & $100^{\mathrm{b}}$ \\
2 & $45^{\mathrm{bc}}$ & $55^{\mathrm{bc}}$ & $0^{\mathrm{b}}$ & $100^{\mathrm{b}}$ \\
3 & $65^{\mathrm{c}}$ & $35^{\mathrm{ab}}$ & $0^{\mathrm{b}}$ & $100^{\mathrm{b}}$ \\
4 & $50^{\mathrm{bc}}$ & $47.5^{\mathrm{b}}$ & $2.5^{\mathrm{b}}$ & $97.5^{\mathrm{b}}$ \\
5 & $5^{\mathrm{a}}$ & $20^{\mathrm{a}}$ & $75^{\mathrm{a}}$ & $25^{\mathrm{a}}$ \\
\hline
\end{tabular}


indicating the efficiency of benzyl amino purine over other cytokinins in enhancing shoot proliferation (Anjusha and Gangaprasad, 2016). In th present study, kinetin appeared to be a relatively weak cytokinin for in vitro multiplication of Impatiens hawkeri, as it did not show any significant increase in shoot proliferation, in comparison to the control. It should be noted that a similar effect was observed in proliferation of Agapanthus praecox and Andrographis lineata, when kinetin was applied as a sole cytokinin (Baskaran and Van Staden, 2013; Mohammed et al., 2016). On the other hand, significantly longer shoots were observed when MS medium was supplemented with one $\mathrm{mgl}^{-1}$ kinetin. These results are in line with the findings of Fajinmi et al. (2014), who observed approximately 1.5 times longer shoots when supplemented kinetin in the culture medium compared to that of benzyl amino purine, TDZ and meta-topolin compounds.

In the present study, the highest proliferation rate was achieved when benzyl amino purine was applied in low concentration $\left(0.5 \mathrm{mgl}^{-1}\right)$. Conversely, along with the increase in benzyl amino purine concentration both shoot proliferation and shoot length decreased markedly. Although benzyl amino purine is accepted as one of the most effective cytokinins in in vitro culture studies (Bairu et al., 2007), its negative impact at higher concentrations has been reported in proliferation of Impatiens repense and Gynochthods umbellate (Anjusha and Gangaprasad, 2016; Herath and Wijesundara, 2010). Commonly, in the next step, the in vitro induced shoots are transferred to the rooting medium consisting of different concentrations of auxins for root induction (Shahzad et al., 2011). However, in this study, all the shoots rooted during proliferation, so transferring the shoots to the rooting medium was not required. It is important to note that acceleration of the rooting process without using rooting medium in our protocol lowers the costs of tissue culture procedure for Impatiens hawkeri. This is more remarkable for commercialization of this process, when reducing time and labour expenses are substantially important. Previously, the simultaneous rooting during shoot regeneration has been stated as an advantage for the micropropagation process of certain plants (Agarwala et al., 2010). The results also showed that axillary derived shoots generated the highest root number in the media containing one $\mathrm{mg} \mathrm{l}^{-1}$ benzyl amino purine. The higher concentration of benzyl amino purine hindered root induction in the medium so that least root number was induced in the medium containing $4 \mathrm{mg} \mathrm{l}^{-1}$ benzyl amino purine by apical buds (0.08). Furthermore, root regeneration and length in the medium supplemented with different concentrations of kinetin were lower compared to those in control, however, no significant differences were observed with regards to this. In the present study, the rooted plantlets were successfully planted in greenhouse after four weeks of culture with more than $95 \%$ of survival rate. All established plants performed well and reached the normal and vigorous growth after six weeks of growth in the greenhouse condition.

The findings of the study clearly indicate that presence of a low concentration of benzyl amino purine in the culture media had a significant and positive impact on the multiplication rate of

Table 3 : Effect of type and concentrations of cytokinins on adventitious shoot proliferation and root induction of Impatiens hawkeri 'Cherry Red' after 10 weeks of culture

\begin{tabular}{|c|c|c|c|c|c|c|}
\hline Treatments & Bud type & Shoot no. & Shoot length & Leaf no. & Root no. & Root length \\
\hline Control & apical & $1.58^{b}$ & $0.61^{\mathrm{ef}}$ & $8.08^{\mathrm{ef}}$ & $7.41^{\text {bcde }}$ & $1.83^{\text {cde }}$ \\
\hline $\begin{array}{l}\text { Benzyl amino purine }\left(\mathrm{mg} \mathrm{l}^{-1}\right) \\
0.5\end{array}$ & apical & $2.42^{\mathrm{ab}}$ & $1.25^{\text {odef }}$ & $9.83^{\text {def }}$ & $11.41^{\text {abcd }}$ & $3.81^{a}$ \\
\hline 1 & apical & $1.92^{\mathrm{ab}}$ & $2.61^{\mathrm{abcd}}$ & $17.92^{\mathrm{abc}}$ & $11.25^{\mathrm{abcd}}$ & $2.5^{\mathrm{abcd}}$ \\
\hline 2 & apical & $2.58^{\mathrm{ab}}$ & $2.04^{\text {abcdef }}$ & $14.17^{\text {abcde }}$ & $6.25^{\text {cde }}$ & $1.38^{\mathrm{def}}$ \\
\hline 4 & apical & $1.75^{\mathrm{ab}}$ & $0.33^{f}$ & $5.08^{f}$ & $0.08^{f}$ & $0.03^{f}$ \\
\hline \multicolumn{7}{|l|}{ Kinetin $\left(\mathrm{mg} \mathrm{l}^{-1}\right)$} \\
\hline 0.5 & apical & $1.17^{b}$ & $1.90^{\text {abcodef }}$ & $6.83^{\mathrm{ef}}$ & $5.58^{\text {def }}$ & $2.58^{\mathrm{abcd}}$ \\
\hline 1 & apical & $1.17^{b}$ & $2.38^{\text {abcde }}$ & $7.42^{\text {ef }}$ & $6.33^{\text {cde }}$ & $2.58^{\mathrm{abcd}}$ \\
\hline 2 & apical & $1.33^{b}$ & $1.64^{\text {bodef }}$ & $11.58^{\text {bcdef }}$ & $7.66^{\text {bode }}$ & $1.41^{\text {def }}$ \\
\hline 4 & apical & $1.17^{b}$ & $2.54^{\text {abcde }}$ & $8.92^{\text {ef }}$ & $7.16^{\text {bcde }}$ & $1.46^{\mathrm{def}}$ \\
\hline Control & lateral & $2.58^{\mathrm{ab}}$ & $1.07^{\text {cdef }}$ & $8.00^{\text {ef }}$ & $8.75^{\text {abcode }}$ & $2.00^{\mathrm{be}}$ \\
\hline Benzyl amino purine $\left(\mathrm{mg} \mathrm{l}^{-1}\right)$ & lateral & $3.42^{\mathrm{a}}$ & $3.46^{\mathrm{ab}}$ & $20.42^{\mathrm{a}}$ & $11.83^{\mathrm{abc}}$ & $2.67^{\text {abcd }}$ \\
\hline \multicolumn{7}{|l|}{0.5} \\
\hline 1 & lateral & $2.08^{\mathrm{ab}}$ & $3.69^{\mathrm{a}}$ & $17.66^{\text {abcd }}$ & $14.17^{\mathrm{a}}$ & $3.31^{\mathrm{abc}}$ \\
\hline 2 & lateral & $2.75^{\mathrm{ab}}$ & $2.82^{\mathrm{abc}}$ & $18.42^{\mathrm{ab}}$ & $13.08^{\mathrm{ab}}$ & $3.42^{\mathrm{ab}}$ \\
\hline 4 & lateral & $2.00^{\mathrm{ab}}$ & $0.86^{\text {def }}$ & $7.25 \mathrm{e}^{f}$ & $4.16^{e f}$ & $0.58^{\mathrm{ef}}$ \\
\hline \multicolumn{7}{|l|}{ Kinetin $\left(\mathrm{mg} \mathrm{l}^{-1}\right)$} \\
\hline 0.5 & lateral & $2.17^{\mathrm{ab}}$ & $2.80^{\mathrm{abcd}}$ & $10.25^{\text {cdef }}$ & $8.33^{\text {abcde }}$ & $1.57^{\mathrm{de}}$ \\
\hline 1 & lateral & $1.58^{\mathrm{b}}$ & $3.30^{\mathrm{ab}}$ & $8.58^{\text {ef }}$ & $5.92^{\text {cdef }}$ & $2.05^{\text {bcde }}$ \\
\hline 2 & lateral & $1.83^{\mathrm{ab}}$ & $2.69^{\mathrm{abcd}}$ & $10.17^{\text {cdef }}$ & $5.25^{e f}$ & $1.46^{\text {def }}$ \\
\hline 4 & lateral & $2.08^{\mathrm{ab}}$ & $2.81^{\mathrm{abcd}}$ & $9.67^{\text {ef }}$ & $6.33^{\text {cde }}$ & $2.50^{\text {abcd }}$ \\
\hline
\end{tabular}


Impatiens hawkeri. Also, axillary explants were more favorable than apical buds in inducing higher shoot number at proliferation stage. The simultaneous occurrence of rooting during proliferation of these explants was remarkably beneficial as it significantly reduced the time and cost of micropropagation procedure. The results proposed a simple protocol which was tested successfully. This protocol recommends a fast, efficient and economic procedure that can be easily commercialized for micropropagation of Impatiens hawkeri 'Cherry Red'.

\section{Acknowledgment}

This work was supported by the Ferdowsi University of Mashhad through grant no. 38646 .

\section{References}

Agarwala, B., F.S. Azam, M.A. Khatun, F. Rahman and M. Rahmatullah: Simultaneous shoot regeneration and rhizogenesis of Wedelia chinensis for in vitro clonal propagation. Am.-Eurasian J. Sustain. Agric., 4, 65-70 (2010).

Anjusha, S. and A. Gangaprasad: In vitro propagation and anthraquinone quantification in Gynochthodes umbellata (L.) Razafim and B. Bremer (Rubiaceae)-A dye yielding plant. Ind. Crops Prod., 81,8390 (2016).

Bairu, M.W., W.A. Stirk, K. Dolezal and J. Van Staden: Optimizing the micropropagation protocol for the endangered Aloe polyphylla: Can meta-topolin and its derivatives serve as replacement for benzyladenine and zeatin? Plant Cell Tissue Organ Cult., 90,15-23 (2007).

Barampuram, S., G. Allen and S. Krasnyanski: Effect of various sterilization procedures on the in vitro germination of cotton seeds. Plant Cell Tissue Organ Cult., 118, 179-185 (2014).

Baskaran, P. and J. Van Staden: Rapid in vitro micropropagation of Agapanthus praecox. S. Afr. J. Bot., 86, 46-50 (2013).

Brunner, I., A. Echegaray and A. Rubluo: Isolation and characterization of bacterial contaminants from Dieffenbachia amoena Bull, Anthurium andreanum Linden and Spathiphyllum sp. Schoot cultured in vitro. Sci. Hort., 62, 103-111 (1995).

Dostal, D.L., N.H. Agnew, R.J. Gladon and J.L. Weigle: Ethylene, simulated shipping, STS and AOA affect corolla abscission of New Guinea impatiens. Hort. Sci., 26, 47-49(1991).

Fajinmi, O., S. Amoo, J. Finnie and J. Van Staden: Optimization of in vitro propagation of Coleonema album, a highly utilized medicinal and ornamental plant. S. Afr. J. Bot., 94, 9-13 (2014).

Fang, J.Y. and Y.R. Hsu: Molecular identification and antibiotic control of endophytic bacterial contaminants from micropropagated Aglaonema cultures. Plant Cell Tissue Organ Cult., 110, 53-62 (2012).

George, E.F.: Plant propagation by tissue culture. Part 1: The Technology. $2^{\text {nd }}$ Edn. : Exegetics Limited, Edington, Britain, pp. 403-455 (1993).

Ghanti, K., C. Kaviraj, R. Venugopal, F. Jabeen and S. Rao: Rapid regeneration of Mentha piperita L. from shoot tip and nodal explants. Indian J. Biotechnol., 3, 594-598 (2004).

Han, K. and L.C. Stephens: Growth regulators affect in vitro propagation of two interspecific Impatients hybrids. Sci. Hort., 32, 307-313 (1987)

Herath, H. and D. Wijesundara: Large-scale in vitro propagation of Impatiens repens Moon., a critically endangered medicinal plant in
Sri Lanka. Hort. Sci. Biotechnol., 85, 211-214 (2010).

Jain, S.M. and S.J. Ochatt: Protocols for in vitro propagation of ornamental plants. Humana Press, London, pp. 117-118 (2010).

Kehie, M., S. Kumaria and P. Tandon: In vitro plantlet regeneration from nodal segments and shoot tips of Capsicum chinense Jacq. cv. Naga King Chili. 3Biotech, 2, 31-35 (2012).

Kim, B.S., K.S. Baek, C.H. Pak, G.H. Park and H.D. Shin : First report of leaf spot caused by Cercospora fukushiana on New Guinea Impatiens in Korea. Plant Dis., 98, 1280 (2014)

Kitto, S.: Micropropagation of Spigelia marilandica L. In Vitro Cell. Dev. Biol. Plant, 51, 205-213 (2015).

Mohammed, A., K.K. Chiruvella and R.G. Ghanta: In vitro plant regeneration, flowering and fruiting from nodal explants of Andrographis lineata nees (Acanthaceae). J. Crop Sci. Biotechnol., 19, 195-202 (2016).

Murashige, T. and F. Skoog : A revised medium for rapid growth and bio assays with tobacco tissue cultures. Physiol. Plant, 15, 473-497 (1962).

Niedz, R.P. and M.G. Bausher: Control of in vitro contamination of explants from greenhouse and field grown trees. In Vitro Cell. Dev. Biol. Plant, 38, 468-471(2002).

Nikolova, R., N. Lall and A. Bosa: An assessment of the conditions for the rapid propagation of Impatiens flanaganae in-vivo and in-vitro. In : International Symposium on Plant Production in Closed Ecosystems (Eds.: E., Goto K. Kurata, M. Hayashi and S. Sase) Springer, Narita, Japan, p. 633 (1996).

Ramseh, M., R. Marx, G. Mathan and S.K. Pandian: Effect of bavistin on in vitro plant conversion from encapsulated uninodal microcuttings of micropropagated Bacopa monnieri L.-An ayurvedic herb. J. Environ. Biol., 30, 441-444 (2009).

Ronghua, L. and F. Zheng: Effects of aluminium on growth and flower color of Impatiens hawkeri. J. Agric. Univ. Hebei., 29, 32-36 (2006).

Salehi, M., B. Hosseini and Z. Jabbarzadeh: High-frequency in vitro plantlet regeneration from apical bud as a novel explant of Carum copticum L. Asian Pac. J. Trop. Biomed., 4, 424-428 (2014).

Shahzad, A., S. Parveen and M. Fatema: Development of a regeneration system via nodal segment culture in Veronica anagallis-aquatica L.-an amphibious medicinal plant. Plant Interact., 6, 61-68 (2011).

Shukla, S.P. and P.B. Khare:In-vitro shoot regeneration via caulogenesis in fern, Pteris vittata L. J. Environ. Biol., 33, 683-687 (2012).

Stephens, L.: Formation of unreduced pollen by an Impatiens hawkerix platypetala interspecific hybrid. Hereditas, 128, 251-255 (1998).

Taha, A., A. Wagiran, H. Ghazali, F. Huyop and G. Parveez: In vitro regeneration of garden balsam, Impatiens balsamina using cotyledons derived from seedlings. Biotechnol., 8, 44-52 (2009).

Tiwari, V., R.P. Singh, B.D. Singh, B, P. Singh, M.K. Singh and R.K. Singh: Comparative analysis on the effect of trimethoprim and bavistin on direct shoot regeneration in Brahmi (Bacopa monniera) in growth regulator free MS medium. J. Environ. Biol., 37, 383-390 (2016).

Vasudevan, R. and J. Van Staden: Cytokinin and explant types influence in vitro plant regeneration of Leopard Orchid (Ansellia africana Lindl.). Plant Cell Tissue Organ Cult., 107, 123-129 (2011).

Wang, Y., J.P. Luo, Z.J. Wei and J.C. Zhang: Molecular cloning and expression analysis of a cytokinin oxidase (DhCKX) gene in Dendrobium huoshanense. Mol. Biol. Rep., 36, 1331-1338 (2009).

Witomska, M. and A. Lukaszewska: Effect of cytokinin concentration and explant type on micropropagation of Impatiens $x$ walleriana Hook. Annals of Warsaw Agricultural University. Hort. (Landsc. Arch.), 24,35-40 (2003). 